\title{
Fehlerkorrekturen bei stereologischen Messungen an menschlichen Plazenten:2. Die Schnittstauchung
}

An Paraffinschnitten von menschlichen Geburtsplazenten wurde mit Hilfe des Integrationsokulares Zottenvolumen und -oberfläche bestimmt. Paraffinschnitte können aber trotz dem Strecken auf der Heizplatte um einen gewissen Prozentsatz in Richtung der Messerführung gestaucht bleiben ${ }^{1}$. Es galt daher festzustellen, wie gross das Ausmass dieser Stauchung ist und inwiefern das Messergebnis durch die Stauchung beeinflusst wird.

Untersuchungsmaterial und Ausmass der Stauchung. Aus verschiedenen Regionen von menschlichen Geburtsplazenten wurden Stiicke in Carnoy'schem Gemisch fixiert und über Benzylbenzoat und Benzol in Paraffin von $56^{\circ} \mathrm{C}$ Schmelzpunkt eingebettet. Von diesen Blöcken wurden auf einem Reichert-Mikrotom Serienschnitte angefertigt und auf einer Heizplatte bei $45^{\circ} \mathrm{C}$ gestreckt. Von jedem Block wurden Schnittdicken von 2, 4, $6 \ldots$ bis $20 \mu$ hergestellt und zwar in unregelmässiger Reihenfolge der verschiedenen Schnittdicken, um den Einfluss eines allfällig vorhandenen Gradienten im Gewebe auszuschalten. Gefärbt wurden die Schnitte teils mit Azan, teils mit Hämalaun-Benzopurpurin.

An jedem Schnitt wurde die Höhe des Gewebsstückes in der Schnittrichtung vor dem Schneiden und nach dem Schneiden und Strecken gemessen. Wie die Figur zeigt, beträgt für Schnitte von $2 \mu$ bei den untersuchten Plazenten die verbleibende Stauchung bis $20 \%$, mit zunehmender Schnittdicke wird sie geringer und sinkt bei Schnitten von $25 \mu$ Dicke praktisch auf Null. Im Unterschied zur Gewebsschrumpfung erfolgt die Stauchung nur in einer Richtung. Die Zotten werden dadurch in einer Richtung linear verkleinert. Eine kompensatorische Ausdehnung nach der Seite wurde nicht beobachtet.

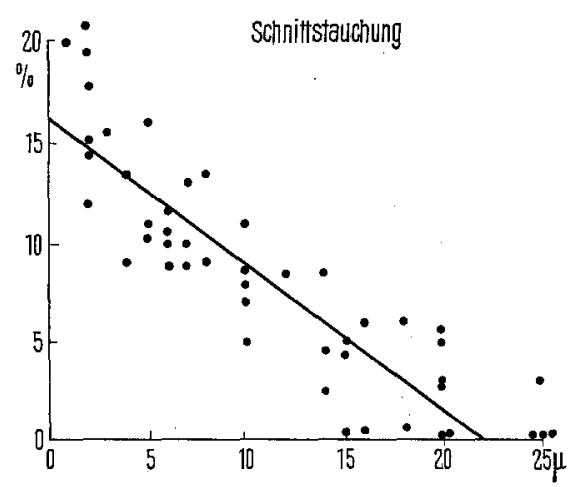

Ausmass der Schnittstauchung in Abhängigkeit von der Schnittdicke, bei Paraffinschnitten menschlicher Plazenten. Ausgehend von $20 \%$ bei dünnen Schnitten wird die Stauchung mit zunehmender Schnittdicke geringer.

\section{Electron Microscopy of Formation of Statoconia}

From the material for a mainly light microscopic and microradiographic study concerning the formation of statoconia in utriculus and sacculus in the embryonic mouse labyrinth, the result of which will be published elsewhere ${ }^{1}$, some 15 days old embryos were fixed for electron microscopic investigation. The 15th day after conception is crucial in the development of statoconia, in that it is the first period in which crystalline calcium
Einfluss der Stauchung. Der Einfluss der Stauchung auf das Messergebnis wurde durch Ausmessen von gezeichneten Testfeldern untersucht, bei denen der Grad der Stauchung genau bestimmt und nach Belieben variiert werden kann. Es ist dies - unter Verwendung von anderen Testfeldern das entsprechende Verfahren, wie es zur Bestimmung des Einflusses der Schrumpfung angewendet wurde ${ }^{2}$.

Wie die Ausmessung der Testfelder ergab, hat die Stauchung auf die Messung des Volumens der Zotten pro Raumeinheit keinen Einfluss, da, im glejchen Masse wie die Zotten verkleinert werden, auch mehr solcher Zotten ins Bildfeld rücken. Die Oberfläche pro Raumeinheit jedoch, die man durch Ausmessen dieser grösseren Anzahl von verkleinerten Zotten erhält, ist $z u$ gross und muss durch Multiplikation mit dem Faktor $1 /(1+q / 2)$ korrigiert werden, wobei $q$ den als Dezimalbruch ausgedrückten Prozentsatz der Stauchung bezeichnet. Bei einer Stauchung von beispielsweise $10 \%$ beträgt also der Korrekturfaktor, mit dem die gemessene Oberfläche multipliziert werden muss, $1 /(1+0,05)=0,953$. Um der tatsächlichen Oberfläche noch näher zu kommen, muss zusätzlich noch der Einfluss der Schrumpfung korrigiert werden ${ }^{2}$. Diese an den Testfeldern erhobenen Befunde gelten unter der Vorausstzung, dass die Zotten im gleichen Verhältnis wie das Paraffin im intervillösen Raum gestaucht werden. Soweit die bisherigen Messungen gezeigt haben, scheinen unsere Präparate dieser Voraussetzung zu genügen.

Summary. Irreversible compression of the sections, due to cutting on the microtome, which may attain up to $20 \%$ in thin paraffin sections, does not influence stereological measurings of volume per $\mathrm{cm}^{3}$ of human placental villi. The measured villous surface, however, must be corrected by multiplication with $1 /(1+q / 2)$, where $q$ means the percentage of compression, expressed as decimal fraction.

R. BAUR ${ }^{3}$

Abteilung Anatomie der Rhein.-Westf.

Technischen Hochschule Aachen,

D-51 Aachen (Deutschland), 3. September 1969.

1 H. Sitre, in Quantitative Methods in Morphology (Ed. E. R. Weibel und H. Elias; Springer, Berlin-Heidelberg-New York 1967), p. 190 . - S. M. Blinkoy und I. I. GLEzER, Das Zentralnervensystem in Zahlen und Tabellen (Fischer, Jena 1968), p. 26. - R. BAur, Acta anat. 66, 631 (1967).

2 R. BAUR, Experientia 25, im Druck (1969).

3 Arbeit mit Unterstititung durch die Deutsche Forschungsgemeinschaft.

salts bound to light microscopically discernible separate elements can be found in the statoconial membranes ${ }^{1,2}$ Although it is well established now that the 'hearing

1 V. B. Veenhof, Verh. K. Akad. Wet. II, 58, 4 (1969).

${ }^{2}$ M. F. Lyon, J. Embryol. exp. Morph. 3, 213 (1955). 